\title{
Primary osteogenic sarcoma of the mediastinum
}

\author{
T AKAAKI IKEDA ${ }^{1}$, TSUNEO ISHIHAR A ${ }^{1}$, \\ HIROSH I YOSHIMATS U ${ }^{1}$, KEIICHI KIKUCHI ${ }^{1}$, \\ MASARU MURAKAMI ${ }^{1}$, KOICHI KOBAYASHI, \\ HIROSHI INOUE ${ }^{1}$, and MASAO KASAHARA ${ }^{2}$ \\ Department of Surgery, School of Medicine, Keio University and Department of Pathology, \\ School of Medicine, Fujita-Gakuen University ${ }^{2}$, Tokyo, Japan
}

\begin{abstract}
Ikeda, T., Ishihara, T., Yoshimatsu, H., Kikuchi, K., Murakami, M.; Kobayashi, K.; Inoue, H., and Kasahara, M. (1974). Thorax, 582-588. Primary osteogenic sarcoma of the mediastinum. A 22-year-old man with primary osteogenic sarcoma of the superior mediastinum is reported. This case is the second instance of primary osteogenic sarcoma of the mediastinum and the first case of superior mediastinal origin to be reported. The patient had local recurrence one year after the first operation. After resection of the recurrent tumour with left upper lobectomy and partial pericardectomy followed by radiation, he has been well for more than five years without recurrence.

Extraosseous osteogenic sarcoma of soft tissue is very rare and has been reported in 103 patients. The five-year survival of patients with extraosseous osteogenic sarcoma is $22.4 \%$. The distribution and prognosis of this tumour are similar to those of rhabdomyosarcoma in soft tissue. Primary amputation or wide excision is the treatment of choice.
\end{abstract}

Extraosseous osteogenic sarcoma arising from soft tissues (Allan and Soule, 1971; Wurlitzer, Ayala, and Romsdahl, 1972) and organs such as the breast (Jernstrom, Lindberg, and Meland, 1963), kidney (Johnson, Ancona, Johnson, and Pineda, 1970), thyroid (Livingstone and Sandison, 1962), urinary bladder (Crane and Tremblay, 1943), uterus (Carleton and Williamson, 1961; Amromin and Gildenhorn, 1962), and lung (Nosanchuk and Weatherbee, 1969; Reingold and Amromin, 1971) is sporadically reported but there has been no report of spontaneous occurrence of osteogenic sarcoma in the superior mediastinum (Benjamin, McCormack, Effler, and Groves, 1972; Conkle and Adkins, 1972).

We have encountered a case of osteogenic sarcoma of mediastinal origin, and we report it as a primary osteogenic sarcoma of the mediastinum.

\section{CASE REPORT}

A 22-year-old well-developed male student was admitted to the Keio University Hospital on 23 August 1968 with a principal complaint of chest pain and mild dyspnoea. The symptoms had developed suddenly one week previously after three days' pyrexia. Until then he had been in good health.
No evidence of anaemia or jaundice was detected. He was $180 \mathrm{~cm}$ tall and weighed $63 \mathrm{~kg}$. The blood pressure was $106 / 52 \mathrm{mmHg}$ and the pulse was regular with a rate of 80 beats/minute. There were no palpable lymph nodes in the supraclavicular region or elsewhere. Dullness to percussion and reduced breath $\underset{\sim}{\varnothing}$ sounds were noted over the left chest anteriorly. No $\dot{0}$ other physical signs were detected.

Examination of the blood revealed the following: haemoglobin $13.5 \mathrm{~g} / 100 \mathrm{ml}$, haematocrit $41.0 \%$, red blood cells $4 \cdot 2 \times 10^{4}$, white blood cells 7,700 , total pro- 0 tein $6.8 \mathrm{~g} / 100 \mathrm{ml}$, serum sodium $142 \mathrm{mEq} / 1$, serum chloride $108 \mathrm{mEq} / 1$, serum potassium $4.0 \mathrm{mEq} / 1$, and $\frac{7}{O}$ serum calcium $5.0 \mathrm{mEq} / 1$. Urine examination revealed a specific gravity of 1.034 , protein and sugar $\tilde{N}$ negative. Urinary sediment showed no abnormality. Urinary excretion of 17-hydroxycorticoids was 6.67 $\mathrm{mg}$ per day and that of 17 -ketosteroids $1.31 \mathrm{mg}$ per $\underset{\mathrm{W}}{\mathrm{N}}$ day. The former was slightly over the normal range, the latter decreased.

Pulmonary function test results were: vital capa- $\frac{O}{\Phi}$ city $2,580 \mathrm{ml}(55 \%)$, maximum voluntary ventilation $\stackrel{\oplus}{\rightleftharpoons}$ $47.0 \mathrm{l} / \mathrm{min}(36 \%)$, and forced expiratory volume in one second $1,870 \mathrm{ml} / \mathrm{sec}(62 \%)$.

The postero-anterior chest radiograph showed a $\stackrel{\mathbb{D}}{\mathbb{D}}$ sharply defined, round mass protruding from the left $\frac{\rho}{\mathbb{D}}$ mediastinal border (Fig. 1). In the lateral view an $\varrho$ elliptical mass was seen in the anterior mid portion of $\bar{\sigma}$ the chest (Fig. 2). The bronchogram revealed posterior 
displacement of the left upper lobe and anterior basal bronchi due to the mass (Fig. 3). With the diagnosis of mediastinal tumour, a left thoracotomy was performed on 4 September 1968. The tumour was located in the superior mediastinum anteriorly adhering to the lingula and the superior parietal pericardium. During dissection of the tumour from the lung, rupture of a part of the tumour occurred and a quantity of yellow serous liquid flowed out. The tumour, attached to the thymus, was removed.

The specimen measured $13 \times 9 \times 7 \mathrm{~cm}$ and was surrounded by a fine fibrous capsule, which appeared fleshy, nodular, and red-brown in colour. The cut surface was nodular, yellowish-grey in colour, elasticfirm in consistency, and contained cysts (Fig. 4). Microscopically the tumour cells were predominantly pleomorphic, and fusiform or polygonal in shape, resembling osteogenic sarcoma or fibrosarcoma. There were irregular areas of osseous and osteoid differentiation surrounded by bizarre multinucleate giant cells and spindle cells containing abundant intranuclear chromatin (Figs 5 and 6). A few mitotic figures were seen. Other areas consisted of well-differentiated eosinophilic cytoplasm. The tumour cells infiltrated the surrounding fibrous capsule. The histological diagnosis established on the basis of these findings was osteogenic sarcoma. A skeletal radiological survey carried out after the operation was negative.

In October 1969 the patient had a chest radiograph and an abnormal shadow was found in the left hilum (Fig. 7), though he had no bronchopulmonary symptoms. He was admitted to hospital for the second time on 20 October 1969.

Physical examination was non-contributory. The chest radiograph showed a round, homogenous density extending from the left hilum, smaller than the primary tumour. Results of blood examinations were: red blood cells $4.2 \times 10^{4}$, haemoglobin 13.6 $\mathrm{mg} / 100 \mathrm{ml}$, haematocrit $44.0 \%$, white blood cells 6,200 , total protein $6.8 \mathrm{mg} / 100 \mathrm{ml}$, serum sodium $140.5 \mathrm{mEq} / 1$, serum chloride $108 \mathrm{mEq} / 1$, serum potassium $4.1 \mathrm{mEq} / 1$, serum calcium $4.7 \mathrm{mEq} / 1$, serum inorganic phosphorus $2 \cdot 2 \mathrm{mEq} / 1$, icterus index 6, SGOT 13, SGPT 9, LDH 110, total cholesterol 174 $\mathrm{mg} / 100 \mathrm{ml}$, and alkaline phosphatase $5 \cdot 6$ units.

A second thoracotomy was performed on 24 October 1969 , with a provisional diagnosis of local recurrence of the tumour. The tumour was about the size of a hen's egg, invading the lingular segment of the upper lobe and the pericardium. Almost complete resection of the tumour could be carried out by removing the left upper lobe and invaded pericardium. The histological findings were identical with those of the original lesion. A lymph node metastasis close to the left main bronchus was resected. The patient developed a haemothorax postoperatively but recovered well without re-operation. Radiation therapy was administered to the superior mediastinum with a dose of $7,000 \mathrm{rad}$. by linear accelerator.

He returned to hospital on 17 June 1970 with symptoms of bloodstained sputum and productive cough. A bronchopleural fistula or local recurrence of the tumour was suspected, and a third thoracotomy was performed on 29 June 1970. The operative diagnosis was pyothorax due to bronchopleural fistula from the superior segment of lower lobe. There was no evidence of recurrence of the tumour grossly or microscopically. He made an uneventful recovery and was discharged on 1 September 1970.

He was readmitted on 21 November 1971 because of sudden haemoptysis. The chest radiograph revealed no change compared with the previous film, though the left lung field was opacified after the operation for pyothorax. Cytological examination of the sputum and bronchoscopic biopsy were negative. Since 1971 he has had occasional bloodstained sputum. He has now survived for more than five years after the first operation without any further evidence of recurrent tumour.

\section{DISCUSSION}

The occurrence of ossification or calcification in degenerative, reactive or neoplastic tissues of the somatic soft parts is not so rare. Osteogenic sarcomata arising in soft tissues are very uncommon. We reviewed 103 extraosseous osteogenic sarcomas reported in the literature. Tables I and II show age, sex, and anatomical distribution.

In 1951 Stauss reported an extraosseous osteogenic sarcoma in the right pleura. Thereafter three cases of osteogenic sarcoma originating in the pleura were reported in the literature (Cohn and Hall, 1968; Pearson, Rubin, Szemes, and Preger, 1969). Hoffmann, Fine, Ponka, and Welborn (1966), Das Gupta, Hadju, and Foote (1968) and Alpert, Abaci, and Werthamer (1973) separately described three cases of osteogenic sarcoma found in the chest wall (Table III). As far as primary

T A B L E I

AGE AND SEX DISTRIBUTION OF 104 PATIENTS WITH EXTRAOSSEOUS OSTEOGENIC SARCOMA

\begin{tabular}{|c|c|c|c|c|c|c|c|c|c|}
\hline & \multirow[b]{2}{*}{ Total } & \multicolumn{8}{|c|}{ Age (years) } \\
\hline & & $0-10$ & $11-20$ & $21-30$ & $31-40$ & $41-50$ & $51-60$ & $61-70$ & 71- \\
\hline $\begin{array}{l}\text { Males } \\
\text { Females }\end{array}$ & $\begin{array}{l}59 \\
45\end{array}$ & 1 & 5 & $\begin{array}{r}12 \\
7\end{array}$ & $\begin{array}{l}7 \\
6\end{array}$ & $\begin{array}{r}10 \\
6\end{array}$ & $\begin{array}{l}13 \\
10\end{array}$ & $\begin{array}{l}11 \\
10\end{array}$ & $\begin{array}{l}1 \\
5\end{array}$ \\
\hline Total & 104 & 1 & 5 & 19 & 13 & 16 & 23 & 21 & 6 \\
\hline
\end{tabular}




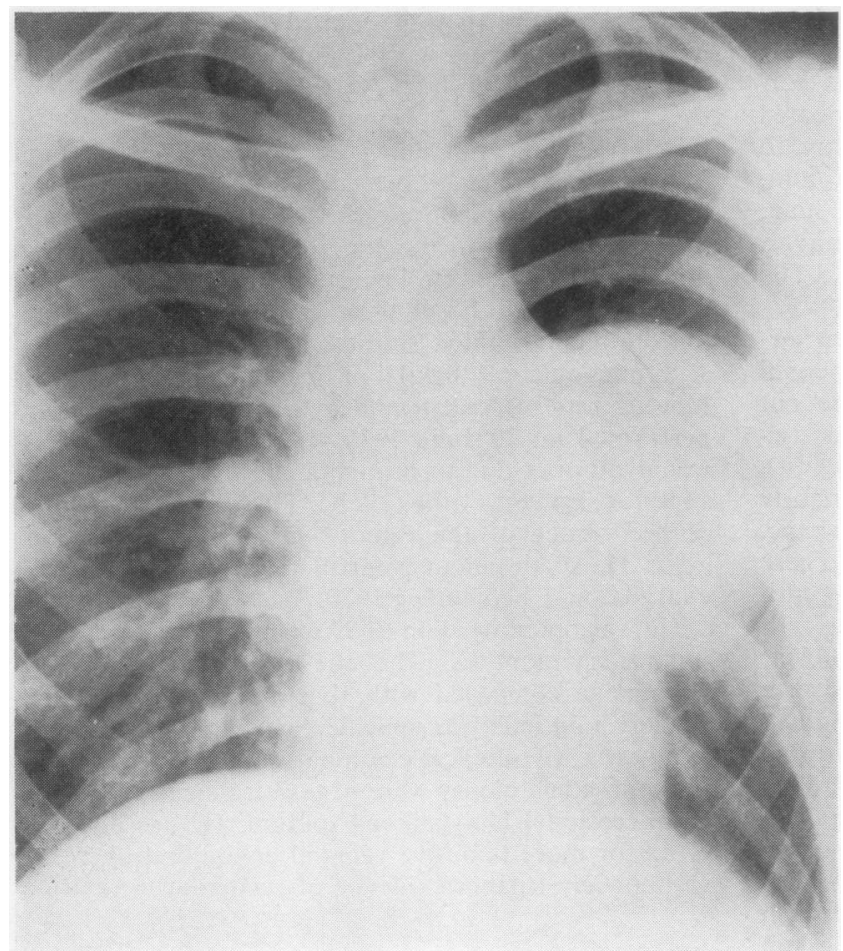

FIG. 1. Chest radiograph at first admissio showing a round, homogenous, and sharpl defined mass protruding from the left medi astinal border.

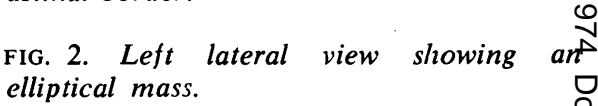

FIG. 3. Bronchogram showing posterio displacement of the upper lobe bronchum and anterior basal bronchus by the mass.

FIG. 1.

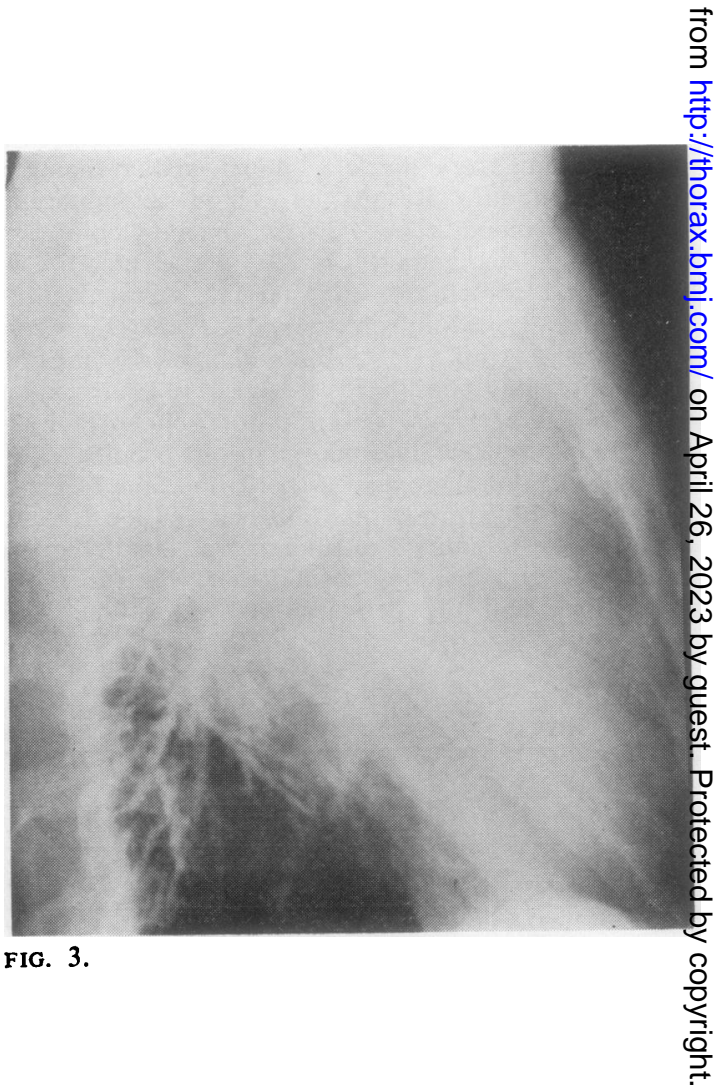




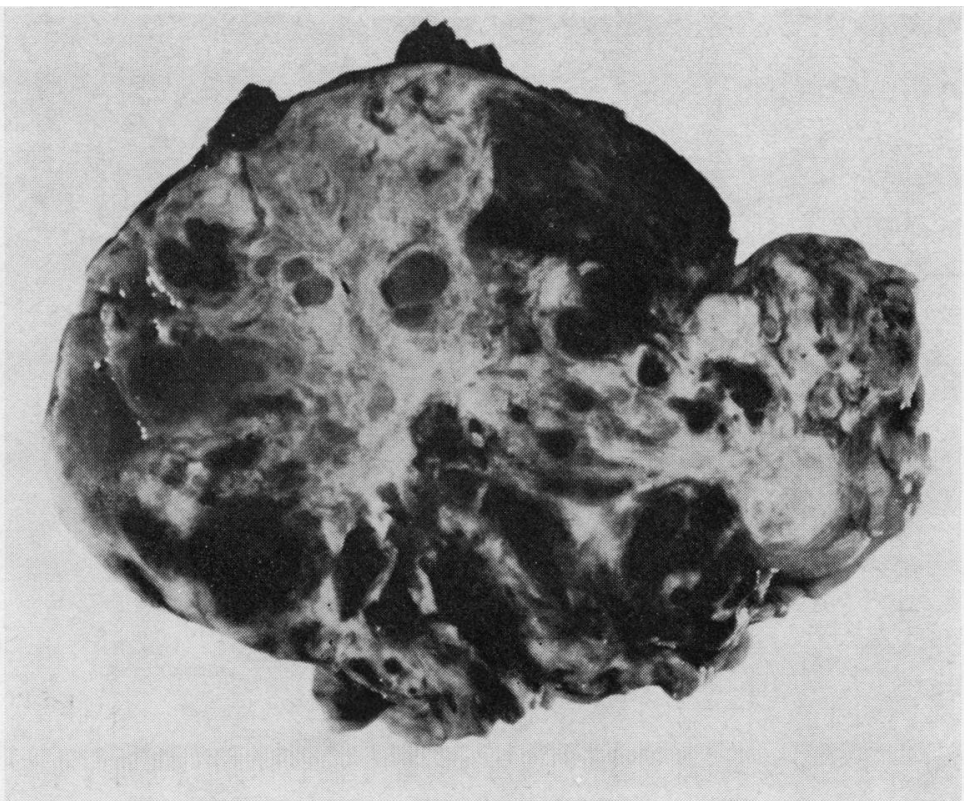

FIG. 4. Cut surface of the resected specimen. Fibrous elements and cystic lesions are seen.

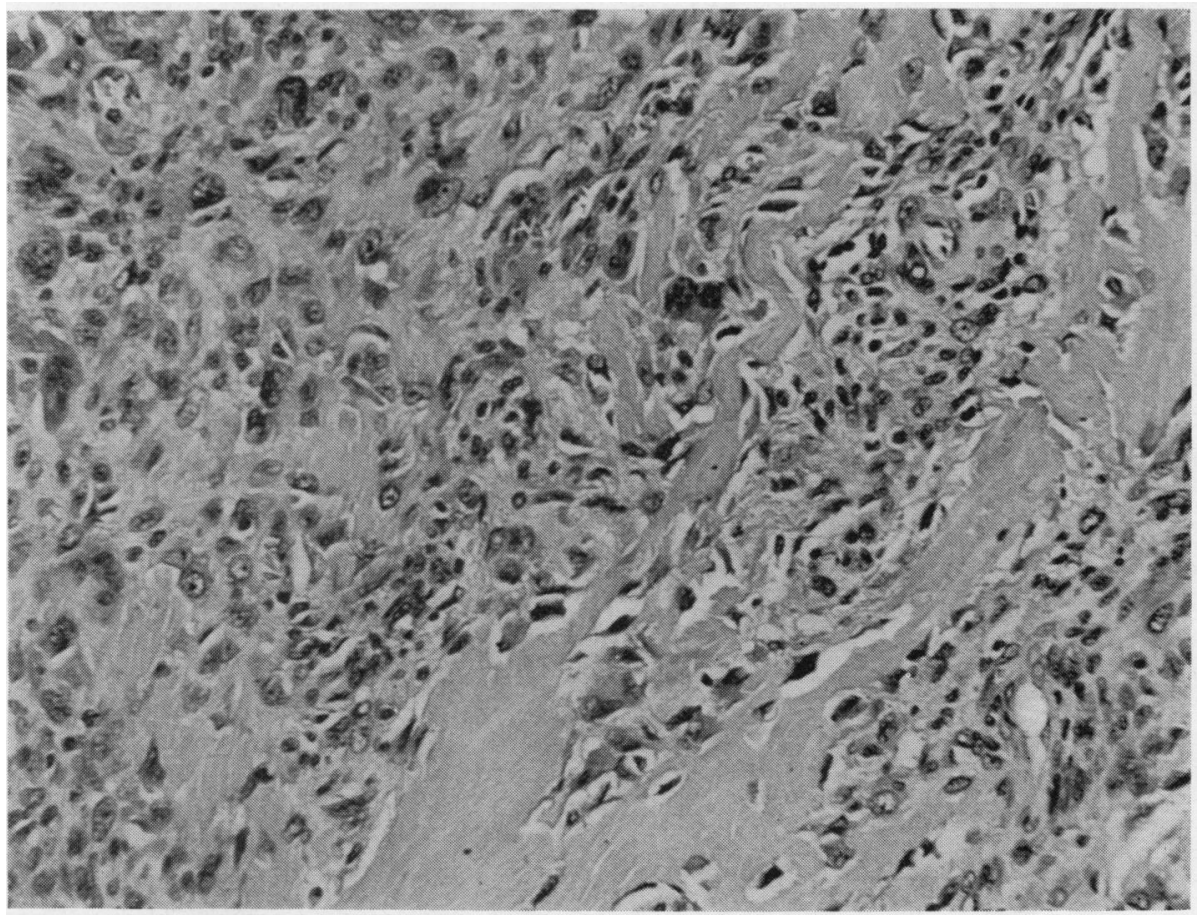

FIG. 5. Microscopical appearance of the tumour showing areas of osseous and osteoid differentiation and fibrosarcomatous elements ( $H$ and $E \times 346)$. 


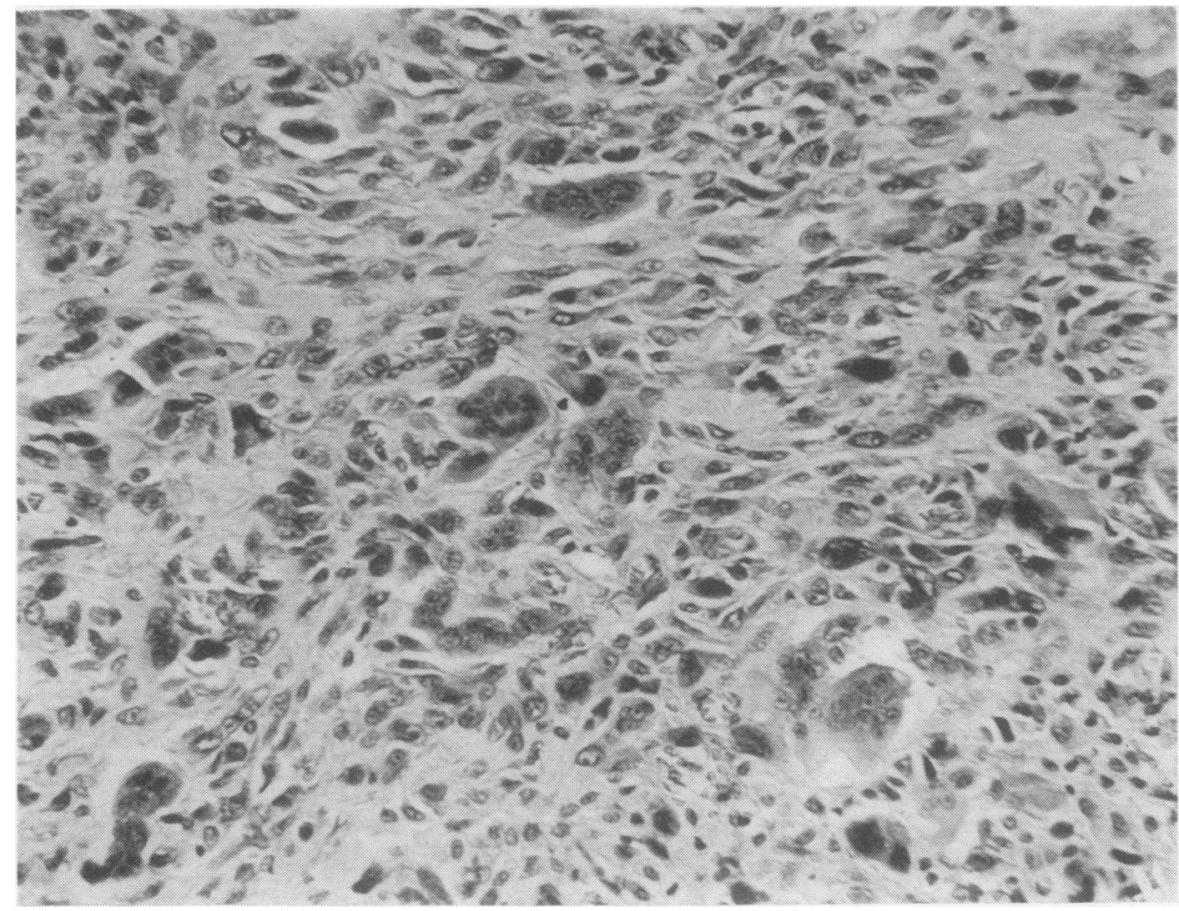

FIG. 6. Areas of bizarre multinuclear giant cells and spindle cells containing abundant intranuclear chromatin $(H$ and $E \times 346)$.

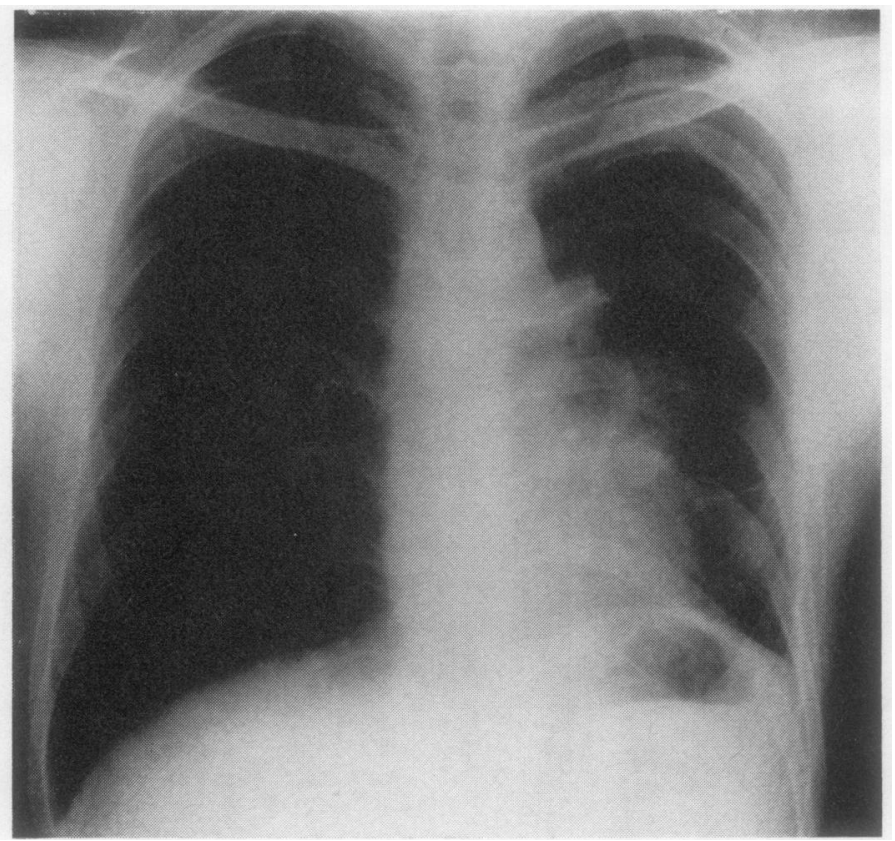

FIG. 7. Chest radiograph at second admission showing a round and homogenous density projecting from the left hilum. 
T A B L E I I

ANATOMICAL SITE OF 104 EXTRAOSSEOUS OSTEOGENIC SARCOMATA

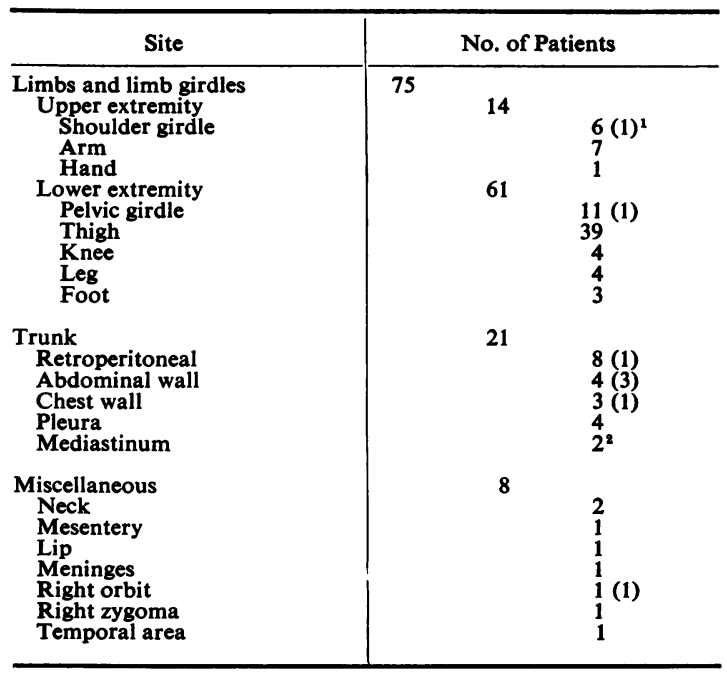

${ }^{1}$ Cases of radiation-induced osteogenic sarcoma are indicated in parentheses.

2Authors' case included. osteogenic sarcoma of the mediastinum is concerned, Wilson (1941) reported a patient with a mediastinal tumour which was proved to be an osteogenic sarcoma at necropsy. This case was later described by Binkley and Stewart (1940) as a primary in the pericardium with metastases to the brain, pancreas, kidney, lungs, and soft tissue of the left iliac fossa and left thigh. Our case is the second instance of primary osteogenic sarcoma of the mediastinum.

Extraosseous osteogenic sarcoma of other organs is also reported, including breast, kidney, thyroid, urinary bladder, and uterus. However, the occurrence of osteogenic sarcoma in thoracic organs is rare. Five cases of primary osteogenic sarcoma of the lung (Reingold and Amromin, 1971) and five cases of osteogenic sarcoma of the heart (Lowry and McKee, 1972) have been reported. In our case the tumour was found at the second operation to invade the lung, but a primary origin from the lung can be denied from the findings at the first operation.

The aetiology of extraosseous osteogenic sarcoma has been discussed as metaplasia of con-

T A B L E I I I

EXTRAOSSEOUS OSTEOGENIC SARCOMA OF THE UPPER TRUNK

\begin{tabular}{|c|c|c|c|c|c|}
\hline Reference & Sex $/$ & Age & Site & Treatment & Course \\
\hline Stauss (1951) & $\mathbf{F}$ & 14 & Right pleura & None & $\begin{array}{l}\text { Died } 7 \text { mth. Tumour involving } \\
\text { right pleura, diaphragm, left } \\
\text { pleura, retroperitoneal tissues, } \\
\text { vertebrae, and rib }\end{array}$ \\
\hline Cohn and Hall (1968) & & 61 & Left upper pleura & Thoracotomy only & $\begin{array}{l}\text { Died shortly after operation. } \\
\text { Metastases to left lung, pleura, } \\
\text { pericardium, and right kidney }\end{array}$ \\
\hline \multirow[t]{2}{*}{ Pearson et al. (1969) } & & 66 & Left lateral pleura & Thoracotomy only & $\begin{array}{l}\text { Died } 5 \text { mth after onset of } \\
\text { symptoms. Metastases to } \\
\text { kidneys and lungs }\end{array}$ \\
\hline & $\mathbf{F}$ & 73 & Left pleura & Thoracotomy only & $\begin{array}{l}\text { Died } 6 \text { mth postop. } \\
\text { Metastases to right lung and } \\
\text { single subcutaneous nodule in } \\
\text { thoracotomy scar }\end{array}$ \\
\hline Hoffmann et al. (1966) & $\mathbf{M}$ & 59 & Left lateral chest wall & $\begin{array}{l}\text { Excision }(2)^{1} \text { Lung } \\
\text { metastasis removed }\end{array}$ & No further follow-up \\
\hline Das Gupta et al. (1968) & $\mathbf{F}$ & 53 & Right posterior chest wall & $\begin{array}{l}\text { Excision (5) }{ }^{1} \text { Chest wall } \\
\text { resection, axillary dissection }\end{array}$ & $\begin{array}{l}\text { Died } 3 \text { yr } 10 \mathrm{mth} \text { after first } \\
\text { excision. Metastases to lungs } \\
\text { and liver }\end{array}$ \\
\hline Alpert et al. (1973) & $\mathbf{F}$ & 41 & Upper anterior chest wall & Excisional biopsy & $\begin{array}{l}\text { Alive } 1 \text { yr without evidence of } \\
\text { tumour recurrence }\end{array}$ \\
\hline Wilson (1941) & $\mathbf{M}$ & 19 & Mediastinum (pericardium) & None & $\begin{array}{l}\text { Died } 2 \mathrm{mth} \text { after admission. } \\
\text { Tumour in base of heart. } \\
\text { Metastases to brain, pancreas, } \\
\text { kidney, and lungs }\end{array}$ \\
\hline Present case & $\mathbf{M}$ & 22 & Superior mediastinum & $\begin{array}{l}\text { Thoracotomy and excision ( } 3)^{1} \\
\text { Irradiation }\end{array}$ & $\begin{array}{l}\text { Alive } 5 \text { yr after first operation } \\
\text { with no further evidence of } \\
\text { tumour }\end{array}$ \\
\hline
\end{tabular}

${ }^{1}$ Number of operations in parentheses. 
nective tissue or embryonal remnant (Amromin and Gildenhorn, 1962; Livingstone and Sandison, 1962; Jussawalla and Desai, 1964; Cohn and Hall, 1968; Lowry and McKee, 1972), while some cases are thought to have been induced by trauma (Fine and Stout, 1956; Järvi, Kvist, and Vainio, 1968) or radiation (Boyer and Navin, 1956; Alpert et al., 1973). In our case the tumour was attached to the thymus but there was no histological relation between the tumour and the thymus. Although teratoma may arise in the anterior superior mediastinum no tissue remnant characteristic of teratoma other than osseous, osteoid, and fibrosarcomatous elements was found in our case. Therefore we conclude that the tumour was primary osteogenic sarcoma of the mediastinum developing from connective tissue metaplasia. The tumour recurred after primary excision; however, the patient has now survived for more than five years without evidence of disease after resection of the recurrent tumour and the left upper lobe followed by irradiation.

These tumours have a very poor prognosis because of their tendency to early metastasis and rapid and widespread local growth. Almost all cases of osteogenic sarcoma in the trunk died of recurrence or metastases. Extraosseous osteogenic sarcoma should be considered in the differential diagnosis of mediastinal, pleural or lung tumours.

\section{REFERENCES}

Allan, C. J. and Soule, E. H. (1971). Osteogenic sarcoma of the somatic soft tissues: clinicopathologic study of 26 cases and review of literature. Cancer, 27, 1121.

Alpert, L. I., Abaci, I. F., and Werthamer, S. (1973). Radiation-induced extraskeletal osteosarcoma. Cancer, 31, 1359.

Amromin, G. D. and Gildenhorn, H. L. (1962). Review of pathogenesis of primary osteogenic sarcoma of the uterus and adnexa: report of two cases. American Journal of Obstetrics and Gynecology, 83, 1574.

Benjamin, S. P., McCormack, L. J., Effler, D. B., and Groves, L. K. (1972). Primary tumors of the mediastinum. Chest, 62, 297.

Binkley, J. S. and Stewart, F. W. (1940). Morphogenesis of extraskeletal osteogenic sarcoma and pseudo-osteosarcoma. Archives of Pathology, 29, 42.

Boyer, C. W. Jr. and Navin, J. J. (1965). Extraskeletal osteogenic sarcoma: a late complication of radiation therapy. Cancer, 18, 628.

Carleton, C. C. and Williamson, J. W. (1961). Osteogenic sarcoma of the uterus. Archives of Pathology, 72, 121.

Cohn, L. and Hall, A. D. (1968). Extraosseous osteogenic sarcoma of the pleura. Annals of Thoracic Surgery, 5, 545.
Conkle, D. M. and Adkins, R. B. Jr. (1972). Primary malignant tumors of the mediastinum. Annals of Thoracic Surgery, 14, 553.

Crane, A. R. and Tremblay, R. G. (1943). Primary osteogenic sarcoma of the bladder: complete re view of sarcomata of the bladder. Annals of Surgery, 118, 887.

Das Gupta, T. K., Hajdu, S. I., and Foote, F. W. Jr (1968). Extraosseous osteogenic sarcoma. Annal. of Surgery, 168, 1011.

Fine, G. and Stout, A. P. (1956). Osteogenic sarcoma of the extraskeletal soft tissues. Cancer, 9, 1027. S

Hoffmann, K., Fine, G., Ponka, J. L., and Welbornir J. K. (1966). Extraskeletal osteogenic sarcoma: case report. Henry Ford Hospital MedicaN Bulletin, 14, 381.

Järvi, O. H., Kvist, H. T. A., and Vainio, P. V. (1968) Extraskeletal retroperitoneal osteosarcoma proes bably arising from myositis ossificans. Act $\$$ Pathologica et Microbiologica Scandinavica, 74 11.

Jernstrom, P., Lindberg, A. L., and Meland, O. Nळ (1963). Osteogenic sarcoma of the mammary gland. American Journal of Clinical Pathology 40, 521 .

Johnson, L. A., Ancona, V. C., Johnson, T., and Pineda, N. B. (1970). Primary osteogenic saro coma of the kidney. Journal of Urology, 104, 528

Jussawalla, D. J. and Desai, J. G. (1964). Primary osteogenic sarcoma arising in extra-skeletal sof tissues of the neck. British Journal of Surgery 51, 504 .

Livingstone, D. J. and Sandison, A. T. (1962). Osteo을 genic sarcoma of thyroid. British Journal of Surgery, 50, 291.

Lowry, W. B. and McKee, E. E. (1972). Primary osteosarcoma of the heart. Cancer, 30, 1068.

Nosanchuk, J. S. and Weatherbee, L. (1969). Primarw osteogenic sarcoma in lung: report of a case Journal of Thoracic and Cardiovascular Surgery 58, 242.

Pearson, K. D., Rubin, D., Szemes, G. C., an£ Preger, L. (1969). Extraosseous osteogenic sar coma of the chest. British Journal of Diseases of the Chest, 63, 231.

Reingold, I. M. and Amromin, G. D. (1971). Extra osseous osteosarcoma of the lung. Cancer, 28 . 491.

Stauss, H. K. (1951). Osteogenic sarcoma arising in traumatic hemothorax and hematoma of the thoracic wall. Surgery, 29, 917.

Wilson, H. (1941). Extraskeletal ossifying tumors? Annals of Surgery, 113, 95.

Wurlitzer, F., Ayala, A., and Romsdahl, M. (1972)尽 Extraosseous osteogenic sarcoma. Archives of Surgery, 105, 691.

Requests for reprints to: Takaaki Ikeda, Department尺 of Surgery, School of Medicine, Keio University, 35 Shinanomachi, Shinjuku-ku, Tokyo 160, Japan. 